\title{
PENGARUH BOARD COMPOSITION, AGENCY COST, LIKUIDITAS DAN LEVERAGE TERHADAP FINANCIAL DISTRESS PADA PERUSAHAAN MANUFAKTUR YANG TERDAFTAR DI BURSA EFEK INDONESIA
}

\author{
Lusiana, Indriyenni \\ Universitas Putra Indonesia YPTK Padang, Indonesia \\ lusiana9157@gmail.com
}

\begin{abstract}
ABSTRAK
Penelitian ini bertujuan untuk mengetahui pengaruh Board Composition, Agency Cost, Likuiditas dan Leverage terhadap Financial Distress pada perusahaan manufaktur sektor aneka industry yang terdaftar di BEI tahun 2012-2016. Metode analisis yang digunakan adalah metode analisis linear berganda dan uji hipotesis dengan menggunakan data laporan keuangan perusahaan periode 2012-2016. Hasil Penelitian menunjukkan : 1) secara parsial, Board Composition tidak berpengaruh signifikan terhadap Financial Distress. 2) Agency Cost berpengaruh signifikan terhadap Financial Distress.3) likuiditas tidak berpengaruh signifikan terhadap Financial Distress .4) Leverage tidak berpengaruh signifikan terhadap Financial Distress.5) sedangkan, secara simultan Board Composition, Agency Cost, Likuiditas dan Leverage berpengaruh signifikan terhadap Financial Distres pada perusahaan manufaktur sector aneka industry yang terdaftar di BEI tahun 2012-2016. Koefisien determinasi $\left(R^{2}\right)$ atas variabel Board Composition, Agency Cost, Likuiditas, dan Leverage terhadap Financial Distres sebesar $70.20 \%$.
\end{abstract}

Kata kunci : Board Composition, Agency Cost, Likuiditas, Leverage, Financial Distres

\section{PENDAHULUAN}

Krisis keuangan atau financial distress sesungguhnya telah terjadi berulang kali di berbagai belahan dunia, termasuk Indonesia. Kondisi financial distress telah tercermin sejak pertengahan tahun 2013 ketika bank sentral Amerika Serikat mengumumkan rencana penghentian kebijakan stimulus moneter. Rencana penghentian tersebut mengakibatkan sejumlah negara terutama negara berkembang mengalami tekanan cukup berat dikarenakan nilai tukar mata uang bergerak fluktuatif dengan kecenderungan melemah.

Pada tahun 2015, Indonesia kembali dihadapkan dengan persoalan melemahnya nilai tukar rupiah terhadap dolar AS yang menembus angka 14.728 per dollar AS pada tanggal 29 September 2015 (website resmi Bank Indonesia). Angka tersebut merupakan level terlemah rupiah sejak awal tahun 2015 dan hal tersebut menimbulkan kekhawatiran tersendiri bagi sebagian besar masyarakat akan kembalinya masa krisis seperti tahun 1998 dan tahun 2008.

Bahkan dampak yang ditimbulkan dari krisis tahun 1998 tersebut yakni ditutupnya 16 bank setelah terjadi rush (penarikan) besar - besaran oleh nasabah bank tersebut sehingga kehilangan likuiditasnya. Krisis kemudian menjalar ke belahan Asia terutama negara-negara seperti Jepang, Korea, China, Singapura, Hongkong, Malaysia, Thailand termasuk Indonesia yang sudah lama memiliki surat-surat berharga perusahaanperusahaan tersebut. 
Pada tahun 2015 laju perekonomian global mengalami ketidakstabilan. Menurut IMF (International Monitery Bank) pada Januari 2016, dalam World Economic Outlook, pertumbuhan perekonomian di China mengalami perkembangan dan perlambatan yang lebih cepat dari yang diperkirakan.

Hal ini berakibat pada kegiatan impor maupun ekspor di China yang mencerminkan melemahnya investasi dan aktivitas manufaktur.Peristiwa tersebut dapat menyebabkan kekhawatiran kinerja masa depan perekonomian China yang dapat mengalami spillovers ke negara lain melalui perdagangan dan harga komoditas yang melemah, serta mengurangi rasa percaya diri dan meningkatkan volatilitas di pasar keuangan. Aktivitas manufaktur dan perdagangan tetap lemah secara global, yang mencerminkan tidak hanya perkembangan di China, tetapi juga dengan permintaan global dan investasi yang lebih luas, terutama penurunan investasi di industri ekstraktif. Penurunan dramatis dalam impor di sejumlah pasar berkembang dapat menyebabkan kesulitan perekonomian dan juga membebani perdagangan global.

Kondisi tersebut dapat memicu ketidakstabilan perekonomian baik dinegara maju maupun negara berkembang. Salah satu negara yang terkena efek dari kondisi perekonomian tersebut adalah Indonesia. Banyak hal yang ditimbulkan dari kondisi ketidakstabilan yang terjadi di Indonesia yang berdampak negatif pada sektor-sektor vital perekonomian, khususnya perusahaan yang berada di Indonesia. Banyak perusahaan yang terkena dampak goncangan dari kondisi ketidakstabilan perekonomian di Indonesia, tak terkecuali perusahaan manufaktur. Perusahaan manufaktur merupakan perusahaan terbanyak yang terdaftar di Bursa Efek Indonesia. Perusahaan ini dapat mendorong pertumbuhan perekonomian secara cepat dan stabil bagi keseluruhan perekonomian Indonesia Worldbank (2012).

\section{Tinjauan Pustaka}

\subsection{Financial Distress}

Menurut Sudana (2011: 249) menyatakan bahwa penyebab terjadinya kesulitan keuangan (financial distress) dikarenakan oleh faktor ekonomi, kesalahan dalam manajemen, dan bencana alam. Perusahaan yang mengalami kegagalan dalam operasinya akan berdampak pada kesulitan keuangan. Tapi kebanyakan penyebab terjadinya financial distress baik secara langsung maupun tidak langsung adalah karena kesalahan manajemen yang terjadi berulang-ulang.

\subsection{Board Composition}

Menurut Sutedi (2015: 130) Dewan Komisaris adalah organ yang bertugas melakukan pengawasan dan memberikan nasihat kepada direksi dalam menjalankan pengurusan perseroan. Tugas utama dari komisaris independen ini diantaranya menilai dan mengarahkan strategi perusahaan, kebijakan pengendalian risiko, anggaran tahunan, dan rencana usaha; menilai sistem penetapan remunerasi para pejabat yang memegang posisi kunci; memantau dan mengatasi konflik kepentingan; dan memantau proses keterbukaan dan efektifitas komunikasi dalam perusahaan (Warsono et al. 2012).

\subsection{Agency cost}

Menurut Jensen dan Meckling dalam Rani (2017) agency cost dalah biayabiaya yang ditanggung oleh pemegang saham untuk mencegah atau meminimalkan masalah-masalah keagenan dan memaksimumkan keuntungan pemegang saham . Menurut Fachrudin (2011: 38) Agency cost merupakan pemberian insentif yang layak kepada manajer, serta biaya pengawasan untuk mencegah adanya keinginan manajer yang mungkin akan melakukan tindakan yang bertentangan dengan tujuan pemilik saham perusahaan. 


\subsection{Likiuditas}

Menurut Fred weston dalam Kasmir (2015 : 129) merupakan rasio yang menggambarkan kemampuan perusahaan dalam memenuhi kewajiban (utang) jangka pendek. Artinya apabila perusahaan ditagih, perusahaan akan mampu untuk memenuhi utang tersebut terutama utang yang sudah jatuh tempo. Dengan kata lain, rasio likuiditas berfungsi untuk menunjukkan atau mengukur kemampuan perusahaan dalam memenuhi kewajibannya yang sudah jatuh tempo, baik kewajiban kepada pihak luar perusahaan (likuiditas badan usaha) maupun didalam perusahaan (likuiditas perusahaan).

\subsection{Leverage}

Menurut Irham Fahmi (2013: 127) Rasio leverage adalah mengukur seberapa besar perusahaan dibiayai dengan utang. Penggunaan utang yang terlalu tinggi akan membahayakan perusahaan karena perusahaan akan masuk dalam kategori extreme leverage (utang ekstrem) yaitu perusahaan terjebak dalam tingkat utang yang tinggi dan sulit untuk melepaskan beban utang tersebut.

\subsection{Kerangka piker}

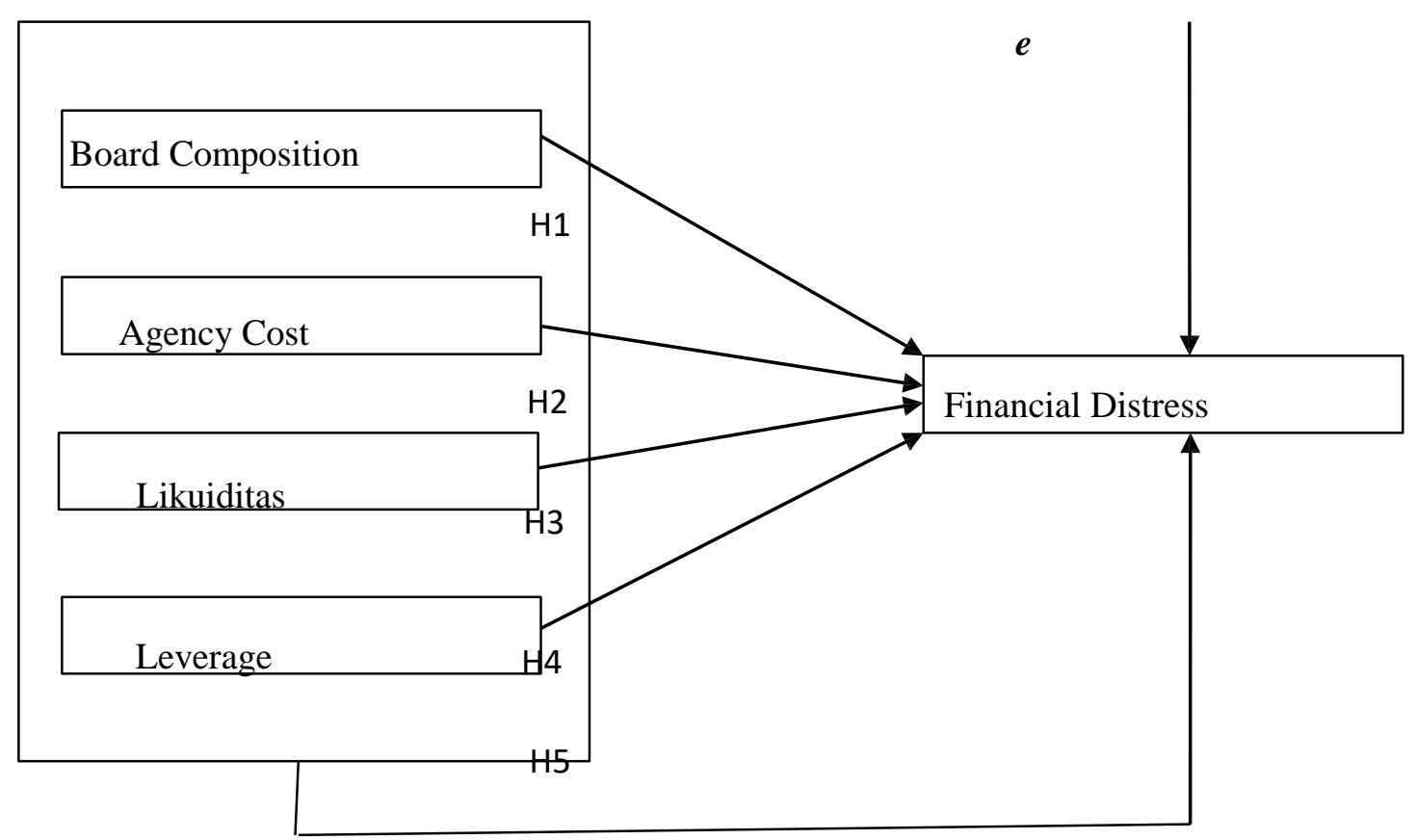




\subsection{Hipotesis}

Berdasarkan tujuan, landasan teori serta kerangka pemikiran teoritis, maka hipotesis yang di ajukan dalam penelitian ini adalah sebagai berikut :

H1 : Diduga Board Commissioners secara parsial berpengaruh dan signifikan terhadap kondisi financial distress perusahaan manufaktur yang terdaftar di BEI

H2 : Diduga Agency Cost secara parsial berpengaruh dan signifikan terhadap kondisi financial distress perusahaan manufaktur yang terdaftar di BEI

H3 : Diduga Likuiditas secara parsial berpengaruh dan signifikan terhadap kondisi financial distress perusahaan manufaktur yang terdaftar di BEI

H4 : Diduga Leverage secara parsial berpengaruh dan signifikan terhadap kondisi financial distress perusahaan manufaktur yang terdaftar di BEI

H5 : Diduga Board Commissioners, Agency Cost, Likuiditas, Leverage secara simultan berpengaruh dan signifikan terhadap kondisi financial distress perusahaan manufaktur yang terdaftar di BEI

\section{Metodologi Penelitian}

\subsection{Populasi Dan Sampel}

\subsubsection{Populasi}

Populasi yang digunakan dalam penelitian ini adalah Perusahaan Manufaktur yang terdaftar Bursa Efek Indonesia pada periode 2012 sampai dengan 2016 yang berjumlah 144 perusahaan.

\subsubsection{Sampel}

Penelitian sampel dalam penelitian ini dilakukan dengan metode purposive sampling, dengan criteria pengambilan sampel sebagai berikut :

1. Perusahaan yang terdaftar di BEI sebagai perusahaan manufaktur yang terdapat di ICMD dari tahun 2012-2016.

2. Perusahaan Manufaktur Sektor Aneka Industri yang terdaftar di Bursa Efek Indonesia tahun 2012-2016.

3. Perusahaan Manufaktur Sektor Aneka Industri yang mengeluarkan data annual report lengkap.

4. Perusahaan Manufaktur Sektor Aneka Industri yang mengeluarkan secara lengkap laporan keuangan berturut-turut dari tahun 2012 hingga 2016

\subsection{Desain Penelitian}

Dalam penelitian yang penulis lakukan ini, penulis menggunakan desain penelitian kuantitatif karena penelitian yang dilakukan penulis berhubungan dengan angka-angka yang kemudian dilakukan perhitungan dari data-data yang telah diperoleh dari Bursa Efek Indonesia dengan periode pengamatan dari tahun 2012 sampai dengan tahun 2016.

\subsection{Sumber Data Dan Teknik Pengumpulan Data \\ 3.3.1 Sumber Data}

Data yang diperlukan adalah data sekunder yaitu data yang sudah diolah pihak perusahaan dan sudah diterbitkan dalam bentuk laporan harga saham atau dengan kata lain data tidak secara langsung diambil dari perusahaan yang bersangkutan yaitu melalui Bursa Efek Indonesia 


\subsubsection{Teknik Pengumpulan Data}

Data yang dibutuhkan dalam penelitian ini adalah data financial distress. Oleh Karena itu, penelitian ini menggunakan data sekunder sebagai data utama.

Tabel 3.1

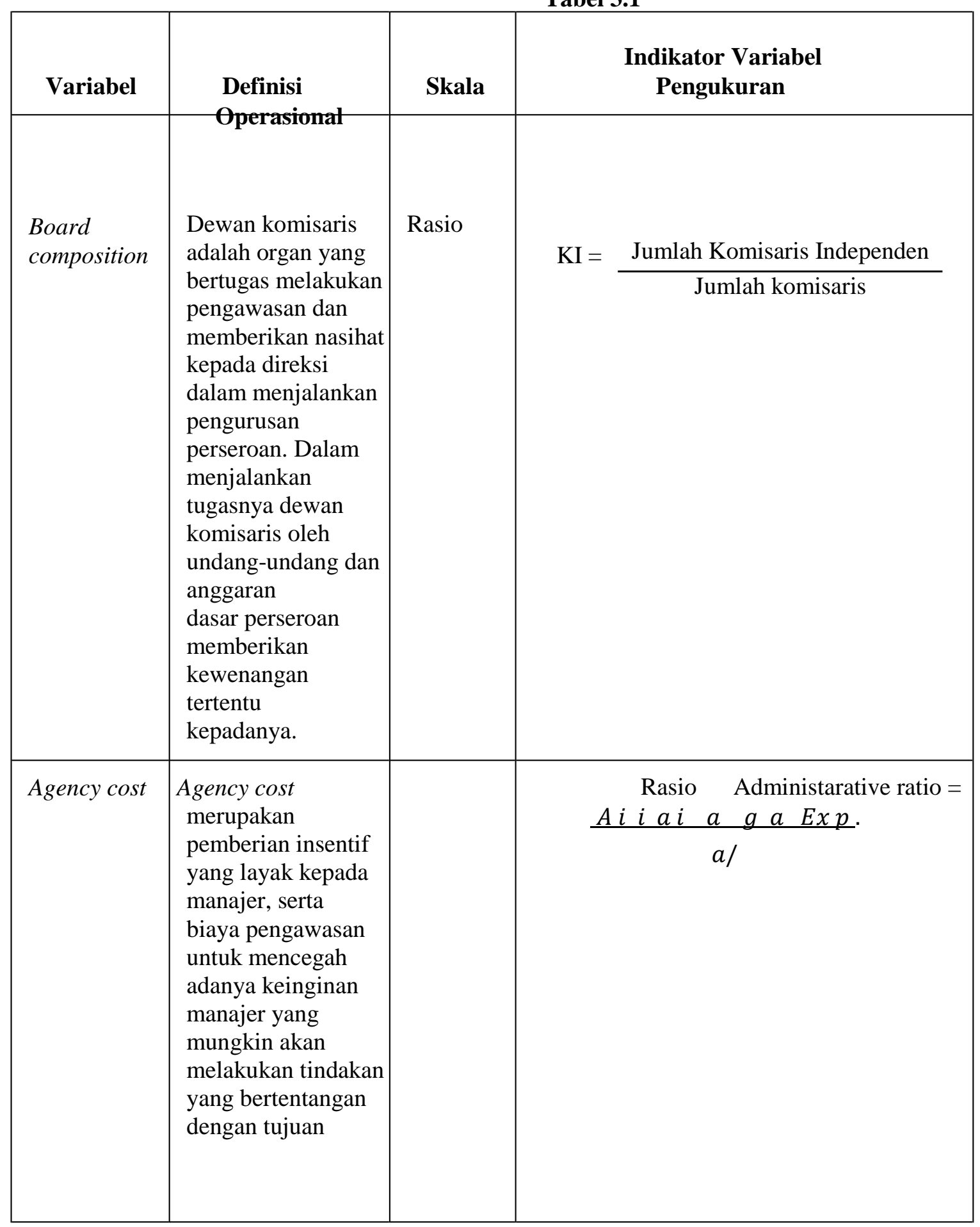




\begin{tabular}{|c|c|c|c|c|}
\hline & pemilik saham. & & Rasio & \\
\hline & $\begin{array}{l}\text { Likuiditas Likuic } \\
\text { perusahaan } \\
\text { menunjukkan } \\
\text { kemampuan perusah } \\
\text { dalam } \\
\text { mendanai operasiona } \\
\text { perusahaan dan melu } \\
\text { kewajiban jangka per } \\
\text { perusahaan. }\end{array}$ & $\begin{array}{l}\text { litas } \\
\text { Ian } \\
\text { nasi } \\
\text { Idek }\end{array}$ & & $\begin{array}{l}\text { Current ratio }(C R)= \\
\frac{a}{\text { hag aa }} \times 100 \%\end{array}$ \\
\hline Leverage & $\begin{array}{l}\text { Rasio leverage adalah } \\
\text { mengukur seberapa b } \\
\text { perusahaan dibiayai } \\
\text { utang. }\end{array}$ & $\begin{array}{l}\text { esar } \\
\text { engan }\end{array}$ & Rasio & $\begin{array}{l}\text { Leverage }=\text { Total Utang } / \text { Total } \\
\text { Modal x } 100 \%\end{array}$ \\
\hline $\begin{array}{l}\text { Financial } \\
\text { distress }\end{array}$ & $\begin{array}{l}\text { Menurut Platt } \\
\text { dan Platt } \\
\text { (Fahmi, 2014:93) } \\
\text { mendefinisikan } \\
\text { financial distress } \\
\text { sebagai tahap } \\
\text { penurunan } \\
\text { kondisi keuangan } \\
\text { yang terjadi } \\
\text { sebelum } \\
\text { terjadinya } \\
\text { kebangkrutan atau } \\
\text { likuiditasi. }\end{array}$ & Rasio & & $I C R=\frac{a i i}{E x} \times 100 \%$ \\
\hline
\end{tabular}

\subsection{Metode Analisis Data}

\subsubsection{Uji Asumsi Klasik}

\section{Uji Normalitas}

Uji normalitas bertujuan untuk mengetahui normal atau tidaknya suatu distribusi data. Uji normalitas adalah membandingkan antara data yang kitamiliki dan data berdistribusi normal yang memiliki mean danstan dardeviasi yang sama dengan kita. Uji normalitas menjadi hal penting karena salah satu syarat pengujian parametric-test (uji parametrik) adalah data harus memiliki distribusi normal (Haryadi, 2013:53).

\section{Uji Multikolonearitas}

Uji multikorelasi bertujuan untuk mengetahui apakah hubungan di antara variable bebas memiliki masalah multikorelasi (gagal multikolinearitas) atau tidak. Multikorelasia dalah korelasi yang sangat tinggi atau sangat rendah yang 
terjadi pada hubungan di antara variable bebas. Uji multikorelasi perlu dilakukan jika variable independen lebih dari satu (Haryadi, 2013:70).

\section{Uji Heterokedasitas}

Menurut (Wijaya, 2013:124), heteroskedastisitas menunjukan bahwa varians variable tidak sama untuk semua pengamat/observasi. Jika varians dari residual satu pengamatan kepengamatan yang lain tetap maka disebut homo kedatisitas. Model regresi yang baik adalah terjadi homo kedatisitas dalam model, atau dengan perkataaan lain tidak heterokedatisitas.

\section{Uji Autokorelasi}

Menurut Wijaya (2013:122), uji autokorelasi bertujuan untuk menguji apakah dalam model regresi linear ada korelasi antara kesalahan pengganggu pada periose $t$ dan kesalahan pengganggu pada periode sebelumnya $(t-1)$. Apabila terjadi korelasi maka hal ini tersebut menunjukan adanya problem autokorelasi

\subsection{Pengujian Hipotesis}

\subsubsection{Secara Silmutan Uji F}

Uji $\mathrm{F}$ digunakan untuk mengetahui apakah permodelan yang dibangun memenuhi kriteria fit atau tidak dengan langkah-langkah berikut:

1. Merumuskan Hipotesis $\mathrm{H} 0: \beta 1, \beta 2, \beta 3, \beta 4=0$ (tidak ada pengaruh board composition, agency cost, likuiditas, dan leverage terhadap financial distress)

Ha : $\beta 1, \beta 2, \beta 3, \beta 4 \neq 0$ (ada pengaruh board composition, agency cost, likuiditas, dan leverage terhadap financial distress)

Memilih uji statistic, memilih uji $\mathrm{F}$ karena hendak menentukan pengaruh berbagai variable independen secara bersama-sama terhadap variable dependen.

2. Menentukan tingkat signifikan yaitu $d=0,05$ dan $\mathrm{df}=\mathrm{k} / \mathrm{n}-\mathrm{k}-1$

3. Menghitung F-hitung atau F-statistik dengan bantuan paket program computer SPSS program analisis regresi linear

4. Membandingkan nilai $\mathrm{t}$-hitung dengan F-tabel, dengan ketentuan : apabila nilai $\mathrm{F}$ hitung lebih besar dari $\mathrm{F}$ table maka variable independen signifikan secara bersama-sama terhadap variable dependen (Ghozali, 2012)

\subsubsection{Secara Parsial Uji Statistik T}

Uji ini dilakukan untuk menguji hipotesis 1 sampai dengan hipotesis 4, adapun hipotesis dirumuskan sebagai berikut (Ghozali, 2005). $\mathrm{H} 0: \beta 1, \beta 2, \beta 3, \beta 4=0$ dan $\mathrm{Ha}: \beta 1, \beta 2, \beta 3, \beta 4 \neq 0$

Artinya terdapat pengaruh yang signifikan dari variable independen Xi terhadap variable dependen Y. jika t-hitung .t_tabel $(\alpha, n-k-$ 1), maka H0 diterima. Signifikan antara variable indenpenden terhadap variable dependen dibawah 0,05 . 


\subsubsection{Koefisien Determinasi $\left(\mathbf{R}^{2}\right)$}

Koefisien determinasi $\left(\mathrm{R}^{2}\right)$ dimaksudkan untuk mengetahui seberapa jauh kemampuan model dalam menerangkan variasi variable dependen (Ghozali, 2012).

Salah satu unsure yang menjadi perhatian dalam analisis regresi ini adalah koeisien determinasi yang biasa disimbolkan dengan R kuadrat (R-square). Biasanya koefisien determinasi $\left(\mathrm{R}^{2}\right.$ ) antara 0 (tidak ada pengaruh) sampai dengan 1 (pengaruh sempurna). Koefisien determinasi merupakan alat ukur yang digunakan untuk mengetahui sejauh mana tingkat hubungan variable independen dan variable dependen. Koefisien ini dapat ditentukan berdasar hubungan antara dua macam variabale, yaitu (1) variasi variabel Y terhadap garis regresi dan (2) variasi variable Y terhadap rata-ratanya.

\section{Hasil dan pembahasan}

\subsection{Uji Hipotesa Secara Parsial (Uji T)}

\section{Hasil Uji T}

\begin{tabular}{|c|c|c|}
\hline Variabel Independen & Probabilitas & Signifikansi \\
\hline \hline Board Composition (X1) & 0,05 & 0,416 \\
\hline \hline Agency Cost (X2) & 0,05 & 0,000 \\
\hline \hline Likuiditas (X3) & 0,05 & 0,262 \\
\hline Leverage (X4 & 0,05 & 0,937 \\
\hline
\end{tabular}

\section{A. Pengaruh Board Composition Terhadap Financial Distress}

Board Composition tidak berpengaruh signifikan terhadap Financial Distress sektor aneka industri yang terdaftar di BEI . Dari tabel 4.12 diatas terlihat bahwa tingkat signifikan lebih besar dari alpha $(0,416>0,05)$. Maka dapat diambil kesimpulan bahwa secara parsial Board Composition tidak mempunyai pengaruh yang signifikan terhadap Financial Distress sektor aneka industri yang terdaftar di BEI (Ho diterima, Ha ditolak).Keterangan :

Ho : Tidak ada pengaruh yang signifikan antara Board Composition terhadap financial distress sektor aneka indursti yang terdaftar di BEI periode 2012-2016 Ha : Ada pengaruh yang signifikan antara Board Composition terhadap financial distress sektor aneka industri yang terdaftar di BEI periode 2012-2016.

\section{B. Pengaruh Agency Cost Terhadap Financial Distress}

Agency Cost tidak berpengaruh signifikan terhadap Financial Distress sektor aneka industri yang terdaftar di BEI . Dari tabel 4.12 diatas terlihat bahwa tingkat signifikan lebih besar dari alpha $(0,000<0,05)$. Maka dapat diambil kesimpulan bahwa secara parsial Agency Cost mempunyai pengaruh yang signifikan terhadap Financial Distress sektor aneka industri yang terdaftar di BEI (Ho ditolak, Ha diterima). Keterangan :

Ho : Tidak ada pengaruh yang signifikan antara Agency Cost terhadap financial distress sektor aneka indursti yang terdaftar di BEI periode 2012-2016 
Ha : Ada pengaruh yang signifikan antara Agency Cost terhadap financial distress sektor aneka industri yang terdaftar di BEI periode 2012-2016.

\section{Pengaruh Likuiditas Terhadap Financial Disteress}

Likuiditas tidak berpengaruh signifikan terhadap Financial Distress sektor aneka industri yang terdaftar di BEI . Dari tabel 4.12 diatas terlihat bahwa tingkat signifikan lebih besar dari alpha $(0,262>0,05)$.

Maka dapat diambil kesimpulan bahwa secara parsial Likuiditas tidak mempunyai pengaruh yang signifikan terhadap Financial Distress sektor aneka industri yang terdaftar di BEI (Ho diterima, Ha ditolak).

Keterangan :

Ho : Tidak ada pengaruh yang signifikan antara Likuiditas terhadap financial distress sektor aneka indursti yang terdaftar di BEI periode 2012-2016 Ha : Ada pengaruh yang signifikan antara Likuiditas terhadap financial distress sektor aneka industri yang terdaftar di BEI periode 2012-2016.

\section{Pengaruh Leverage Terhadap Financial Disteress}

Leverage tidak berpengaruh signifikan terhadap Financial Distress sektor aneka industri yang terdaftar di BEI . Dari tabel 4.12 diatas terlihat bahwa tingkat signifikan lebih besar dari alpha $(0,937>0,05)$. Maka dapat diambil esimpulan bahwa secara parsial Leverage tidak mempunyai pengaruh yang signifikan terhadap Financial Distress sektor aneka industri yang terdaftar di BEI (Ho diterima, Ha ditolak). Keterangan :

Ho : Tidak ada pengaruh yang signifikan antara Leverage terhadap Financial Distress sektor aneka indursti yang terdaftar di BEI periode 2012-2016

Ha : Ada pengaruh yang signifikan antara Leverage terhadap financial distress sektor aneka industri yang terdaftar di BEI periode 20122016.

\subsection{Uji Hipotesa Secara Simultan (Uji F) Hasil}

\begin{tabular}{|c|c|c|c|c|c|c|}
\hline Model & $\begin{array}{l}\text { Sum of } \\
\text { Squares }\end{array}$ & $\mathrm{Df}$ & $\begin{array}{l}\text { Mean } \\
\text { Square }\end{array}$ & & $\mathrm{F}$ & Sig. \\
\hline $\begin{array}{c}\text { Regression } \\
\text { Residual }\end{array}$ & $\begin{array}{c}6.982 \\
2.247\end{array}$ & $\begin{array}{r}4 \\
18\end{array}$ & $\begin{array}{l}1.746 \\
.125\end{array}$ & 13. & $\begin{array}{ll}983 & .000\end{array}$ & \\
\hline
\end{tabular}

Dari tabel diatas dapat dilihat pengujian ini dilakukan dengan cara membandingkan signifikan ketiga variabel sebesar 0,000 dengan nilai probabilitas sebesar 0,05 . Yang artinya nilai signifikan lebih kecil daripada nilai probabilitas yaitu $0,000<0,05$ maka dapat dikatakan secara bersama-sama variabel independen berpengaruh terhadap variabel dependen

Hal ini berarti Ho ditolak dan Ha diterima, sehingga dapat disimpulkan bahwa jika dilakukan pengujian secara simultan antara Board Composition (X1), Agency Cost (X2) Likuiditas (X3), Leverage (X4) berpengaruh signifikan terhadap Financial Distress sektor aneka Industri yang terdaftar di BEI periode 2012-2016 
Ho: Tidak ada pengaruh secara bersama-sama Board Composition, Agency Cost, Likuiditas dan Leverage terhadap Financial Distress Sektor Aneka Industri yang terdaftar di BEI periode 2012-2016.

Ha : Ada pengaruh secara bersama-sama Board Composition, Agency Cost, Likuiditas dan Leverage terhadap Financial Distress Sektor Aneka Industri yang terdaftar di BEI periode 2012-2016.

\subsection{Interprestasi Hasil Penelitian}

\section{Pengaruh Board Composition terhadap Financial Distress}

Tidak terdapat pengaruh yang signifikan antara variabel Board Composition terhadap financial distress dimana tingkat signifikansi variabel Board Composition adalah sebesar 0,416 yang lebih besar dari alpha yaitu sebesar 0,05 atau $(0,416>0,05)$.

Artinya bahwa Board Composition tidak berpengaruh terhadap financial distress. Hal ini juga berarti Meningkatnya board composition pada suatu perusahaan juga mengindikasikan semakin meningkatnya diversifikasi keahlian, sehingga mampu melakukan evaluasi kinerja manajemen dengan baik serta semakin banyak pula koneksi terhadap pihak eksternal yang dimiliki perusahaan.

Hal ini akan memudahkan perusahaan dalam mengatasi kondisi financial distress, dengan misalnya meminta bantuan terhadap pihak eksternal perusahaan, baik dalam pinjaman dana atau mekanisme lainnya yang mungkin dilakukan untuk menghindari perusahaan dari kebangkrutan

\section{Pengaruh Agency Cost terhadap Financial Distress}

Terdapat pengaruh yang signifikan antara variabel Agency Cost terhadap financial distress dimana tingkat signifikansi variabel Agency Cost adalah sebesar 0,000 yang lebih kecil dari alpha yaitu sebesar 0,05 atau $(0,00>0,05)$.

Artinya bahwa Agency Cost berpengaruh terhadap financial distress. Agency cost adalah biaya - biaya yang dikeluarkan karena adanya pengawasan manajemen agar bertindak sesuai dengan perjanjian kontraktual. Hal ini menyebabkan biaya agen timbul karena adanya konflik antara pemilik perusahaan dan pengelola perusahaan sehingga menyebabkan yang dinamakan konflik keagenan.

\section{Pengaruh Likuiditas terhadap Financial Distress}

Tidak terdapat pengaruh yang signifikan antara variabel likuiditas terhadap financial distress dimana tingkat signifikansi variabel likuiditas adalah sebesar 0,262 yang lebih besar dari alpha yaitu sebesar 0,05 atau $(0,262>$ $0,05)$.

Artinya bahwa likuiditas tidak berpengaruh terhadap financial distress. Hal ini disebabkan oleh perusahaan mampu mendanai dan melunasi kewajiban jangka pendeknya dengan baik maka potensi perusahaan mengalami financial distress akan semakin kecil bahkan bias dihindari.

\section{Pengaruh Leverage terhadap Financial Distress}

Tidak terdapat pengaruh yang signifikan antara variabel leverage terhadap financial distress dimana tingkat signifikansi variabel leverage 
adalah sebesar 0,937 yang lebih besar dari alpha yaitu sebesar 0,05 atau $(0,937>0,05)$.

Artinya bahwa leverage tidak berpengaruh terhadap financial distress. Hal tersebut dapat disebabkan karena perusahaan memiliki total hutang yang tinggi tetapi total aset yang dimiliki perusahaan juga tinggi, sehingga perusahaan mampu membayar hutang menggunakan aset yang dimiliki perusahaan. Perusahaan cenderung lebih berhati-hati dalam memanfaatkan hutang jangka pendek dan jangka panjang dalam penggunaan operasional perusahaan.

\section{Pengaruh Board Composition, Agency Cost, Likuiditas dan Leverage terhadap Financial Distress}

Terdapat pengaruh yang signifikan antara variabel Board

Composition, Agency Cost, Likuiditas dan leverage terhadap financial distress dimana tingkat signifikansi sebesar 0,00 yang lebih kecil dari alpha yaitu sebesar 0,05 atau $(0,00>0,05)$.

Artinya bahwa Board Composition, Agency Cost, Likuiditas dan leverage berpengaruh terhadap financial distress. Hal ini juga berarti meningkatnya board composition pada suatu perusahaan juga mengindikasikan semakin meningkatnya diversifikasi keahlian, sehingga mampu melakukan evaluasi kinerja manajemen dengan baik serta semakin banyak pula koneksi terhadap pihak eksternal yang dimiliki perusahaan. Hal ini akan memudahkan perusahaan dalam mengatasi kondisi financial distress. Perusahaan yang mempertahankan rendahnya agency cost kemungkinan kecil tidak akan mengalami financial distress. Semakin baik penerapan corporate governance suatu perusahaan semakin rendah agency cost yang harus dikeluarkan perusahaan untuk memitigasi adanya agency problem. Hal tersebut dapat menunjukkan bahwa semakin rendah likuiditas maka akan semakin besar pengaruh terhadap kondisi financial distress dan dapat disebabkan karena perusahaan memiliki aset lancar yang kecil digunakan untuk membayar hutang-hutang jangka pendek perusahaan sebelum jatuh tempo. Perusahaan dengan tingkat leverage yang tinggi sehubungan dengan Research and Development adalah subjek yang paling mengalami distress secara ekonomi.

\section{Kesimpulan}

Berdasarkan hasil penelitian yang dilakukan pada 23 perusahaan sector aneka industry tahun 2012-2016 maka dapat diajukan beberapa kesimpulan tentang Pengaruh Board Composition (X1), Agency Cost (X2), Likuiditas (X3) dan Leverage (X4) terhadap Financial Distress (Y) didalam penelitian ini, sebagai berikut:

1. Tidak terdapat pengaruh yang signifikan antara Board Composition terhadap Financial Distress.

2. Terdapat pengaruh yang signifikan antara Agency Cost terhadap Financial Distress.

3. Tidak terdapat pengaruh yang signifikan antara likuiditas terhadap Financial Distress. 
Jurnal EKOBISTEK Fakultas Ekonomi, Vol.7, No. 2, Oktober 2018, Hal 69-81 ISSN : 2301-5268 |E-ISSN : 2527-9483

Copyright@2018 by LPPM UPI YPTK Padang

4. Tidak terdapat pengaruh yang signifikan antara Leverage terhadap Financial Distress.

5. Terdapat pengaruh yang signifikan antara Board Composition, Agency Cost, Likuiditas dan Leverage secara bersama-sama terhadap Financial Distres.

\section{DAFTAR PUSTAKA}

Rani, Dwi Rafika. 2017. Pengaruh Likuiditas, Leverage, Profitabilitas, Agency Cost dan Sales Growth Terhadap Kemungkinan Terjadinya Financial Distress (Studi Empiris Pada Peruasahaan Manufaktur Yang Terdaftar di Bursa Efek Indonesia Tahun 2012-2015). Jom Fekon Vol. 4. No. 1. Faculty Of Economics Riau University, Pekanbaru, Indonesia.

Astuti, Puji. 2014. Analisis Pengaruh Opini Going Concern, Likuiditas, Solvabilitas, Arus Kas, Umur Perusahaan Dan Ukuran Perusahaan Terhadap Kemungkinan Financial Distress. Skripsi. Fakultas Ekonomika Dan Bisnis Universitas Diponegoro.

Huda, Ahmad miftahul. 2017. Pengaruh Corporate Governance Structure Dan Management Agency Cost Terhadap Financial Distress (Studi Pada Perusahaan Di Indeks Saham Syariah Indonesia). Skripsi. Fakultas Ekonomi Dan Bisnis Islam Institut Agama Islam Negeri Surakarta.

Gunawijaya, Ignasia Nathania Astria. Pengaruh Karakteristik Komite Audit, Independensi Dewan Komisaris, Reputasi Auditor Terhadap Financial Distress. Jurnal Akuntansi Bisnis, Vol. XIV No. 27. Universitas Katolik Soegijapranata Semarang.

Triwahyuningtias, Meilinda. 2012. Analisis Pengaruh Struktur Kepemilikan, Ukuran Dewan, Komisaris Independen, Likuiditas Dan Leverage Terhadap Terjadinya Kondisi Financial Distress (Studi Pada Perusahaan Manufaktrur Yang Terdaftar Di Bursa Efek Indonesia Periode Tahun 2008-2010). Skripsi. Fakultas Ekonomika Dan Bisnis Universitas Diponegoro Semarang.

Kusanti, Okta. 2015. Pengaruh Good Corporate Governance Dan Rasio Keuangan Terhadap Financial Distress. Jurnal Ilmu Dan Riset Akuntansi Vol. 4. No. 10. Sekolah Tinggi Ilmu Ekonomi Indonesia (STIESIA) Surabaya.

Irfan, Mochamad. 2014. Analisis Financial Distress Dengan Pendekatan Altman Z"'-score Untuk Memprediksi Kebangkrutan Perusahaan Telekomunikasi. Jurnal Ilmu Dan Riset Manajemen Vol. 3. No. 1. Sekolah Tinggi Ilmu Ekonomi Indonesia (STIESIA) Surabaya.

Andari Dan Wiksuana. 2017. RGEC Sebagai Determinasi Dalam Menanggulangi Financial Distress Pada Perusahaan Perbankan Di Bursa Efek Indonesia. Jurnal Manajemen Unud, Vol. 6, No. 1. Fakultas Ekonomi Dan Bisnis Universitas Udayana, Bali, Indonesia.

Indrasari, Dkk. 2016. Pengaruh Komisaris Independen, Komite Audit, Dan Financial Distress Terhadap Integritas Laporan Kuangan. Jurnal Akuntansi/Volume XX, No. 01. Fakultas Ekonomi Universitas Telkom.

Sari, Patria Endah Juwita Sari. 2014. Pengaruh Agency Cost, Leverage Dan Growth Terhadap Kebijakan Dividen Pada Perusahaan Manufaktur Yang Terdaftar Di Bursa Efek Indonesia. Artikel Ilmiah. Sekolah Tinggi Ilmu Ekonomi Perbanas Surabaya.

Mayangsari, Lillanada Putri. 2015. Pengaruh Good Corporate Governance Dan Kinerja Keuangan Terhadap Financial Distress. Jurnal Ilmu Dan Riset Akuntansi Vol. 4 No. 4. Sekolah Tinggi Ilmu Ekonomi Indonesia (STIESIA) Surabaya.

Rahayu Dan Sopian. 2016. Pengaruh Rasio Keuangan Dan Ukuran Perusahaan Terhadap Financial Distress (Studi Empiris Pada Perusahaan Food And Beverage Di Bursa Efek Indonesia). Jln. Jakarta No. 79 Bandung.

Sunarwijaya, I Ketut. 2016. Pengaruh Likuiditas, Leverage, Kepemilikan Manajerial, Dan Kepemilikan Institusional Terhadap Kemungkinan Terjadinya Financial Distress. Fakultas Ekonomi Universitas Mahasaraswati Denpasar.

Ayuningtias. 2013. Analisis Pengaruh Struktur Kepemilikan, Board Composition, Dan Agency Cost Terhadap Financial Distress. Jurnal Ilmu Manajemen. Jurusan Manajemen, Fakultas Ekonomi, Universitas Negeri Surabaya.

Kristanti, Dkk. 2016. The Determinant Of Financial Distress On Indonesian Family Firm. Procedia - Social And Behavioral Sciences. 3rd Global Conference On Business And Social Science, Kuala Lumpur, Malaysia. 
Witiastuti Dan Suryandari. 2016. The Influence Of Good Corporate Governance Mechanism On The Possibility Of Financial Distress. Review Of Integrative Business And Economics Research, Vol. 5, No. 1. Faculty Of Economics, Semarang State University (UNNES) Semarang, Indonesia.

Anggraini, Dewi. 2014. Financial Distress Model Prediction For Indonesian Companies. International Journal Of Management Administrative Sciences (IJMAS). Faculty Of Economics, Mercu Buana University, Indonesia.

Sutedi, Adrian. 2015. Buku Pintar Hukum Perseroan Terbatas. Jakarta : Raih Asa Sukses.

Ary, Gumanti Tatang. 2017. Keuangan Korporat : Tinjuan Teori Dan Bukti Empiris. Jakarta : Mitra Wacana Media.

Kasmir. 2015. Analisis Laporan Keuangan. Jakarta : Rajawali Pers.

Hery. 2016. Analisis Laporan Keuangan. Jakarta : Pt Gasindo.

Hery. 2015. Analisis Laporan Keuangan. Yogyakarta : CAPS (Center For Academic Publishing Service).

Wiyono Dan Kusuma. 2017. Manajemen Keuangan Lanjutan. Yogyakarta : UPP STIM YKPN.

Fahmi, Irham. 2013. Analisis Laporan Keuangan. Bandung : Alfabeta, Cv.

Fahmi, Irham. 2011. Manajemen Kinerja Teori dan Aplikasi. Bandung : Alfabeta.

Fahmi, Irham .2012. Manajemen Teori, Kasus Dan Solusi. Bandung : Alfabeta.

Fahmi, Irham. 2013. Manajemen Risiko, Teori, Kasus Dan Solusi. Bandung : Alfabeta.

Fahmi, Irham. 2014. Pengantar Manajemen Keuangan. Bandung : Alfabeta.

Ramadhan, Syahril. 2012. Analisis Pengaruh Struktur Kepemilikan, Komisaris Independen, Karakteristik Perusahaan Dan Rasio Keuangan Terhadap Kondisi Financial Distress Pada Perusahaan Publik. Jurnal Akuntansi Bisnis Vol. 4. No.1. Dosen STIE Trisakti.

Warsono, et al. 2012. Corporate Govornance, Concept And Model. Yogyakarta : Center For Good Corporate Govornance.

Kustanti, Okta Dan Andayani. 2015. Pengaruh Good Corporate Governance Dan Rasio Keuangan Terhadap Financial Distress. Jurnal Ilmu Dan Riset Akuntansi Vol. 4. No.40

Mas’ud, Imam Dan Reva Maymi Srengga. 2012. Analisis Rasio Keuangan Untuk Memprediksi Kondisi Financial Distress Perusahaan Manufaktur Yang Terdaftar Di Bursa Efek indonesia. Jurnal Akuntansi Vol. 10. No. 2. Universitas Jember.

Listiana, Susi. 2014. Pengaruh Corporate Governance, Profitabilitas Dan Leverage Terhadap Financial Distress. E jurnal Vol. 10. No. 3. Universitas Udayana.

Fu'adah, Tsamrotul. 2013. Pengaruh Agency Cost Terhadap Kinerja Keuangan BUMN Di Bidang Pertambangan, Industri Strategis, Energi Dan Telekomunikasi (PISET). Fakultas Ekonomi Universitas Negeri Surabaya.

Atika, Dkk. 2013. Pengaruh Beberapa Rasio Keuangan Terhadap Prediksi Kondisi Financial Distress (Studi Pada Perusahaan Tekstil Dan Garment Yang Terdaftar Di Bursa efek indonesia Periode 20082011). Fakultas Ilmu administrasi Universitas Brawijaya.

www.idx.co.id 